Bangladesh J. Sci. Res. 28(2): 91-101, 2015 (December)

\title{
ASSESSMENT OF VULNERABILITY IN AGRICULTURAL SECTOR IN DISASTER PRONE AREAS OF BANGLADESH
}

\author{
T. F. Khan, M. W. Ullah ${ }^{1}$ and S. M. Imamul Huq ${ }^{*}$ \\ Bangladesh Australia Centre for Environmental Research (BACER-DU), Department of Soil, \\ Water and Environment, University of Dhaka, Dhaka-1000, Bangladesh
}

\begin{abstract}
A study was carried out in 24 Upazillas of 12 districts of Bangladesh with a view to identifying risks, vulnerabilities and impacts of different types of natural disasters commonly occurring in Bangladesh with respect to agricultural production and sustainable agricultural development. Three districts were selected from each category of the disaster viz., drought, saline, river flood and flash flood prone. Two Upazillas were selected randomly from each district by considering the homogeneity (climate, agricultural practices, agricultural production, disaster risks, livelihood system, population, etc.) of the particular disaster affected areas. Of the four disasters, drought prone area covers the highest net cultivable area (NCA) measuring about 121 ha. Flash flood, salinity and river flood prone area covers approximately 115, 60 and 30 ha, respectively. The dominant cropping pattern in drought areas is Fallow-T.Aman-Wheat. In saline areas, it is Fallow-T. Aman- Pulse while in flood areas, it is Fallow-T.AmanHYV Boro. Trend analysis shows that overall cropped area decreased by $1 \%$ in all disaster prone areas from 1984 - 2013. The highest decrease in cropped area was found for pulse in both drought (13\%) and river flood (14\%) areas. In saline and flash flood areas, it was for spice and potato, respectively. Among 72 farmers, $85 \%$ is vulnerable to drought, $90 \%$ to salinity, $69 \%$ to river flood and $95 \%$ to flash flood. Medium high land was found to be the most vulnerable for agricultural production in all disaster prone areas. Due to vulnerability to disasters, medium high land remains fallow in saline (83\%), river flood (51\%) and flash flood (31\%) areas. In case of drought regions, medium low land (37\%) remains fallow.
\end{abstract}

Key words: Assessment, vulnerability, disaster pone, crop production

\section{Introduction}

Bangladesh is predominantly an agro-based country. The total cropped area is 15.085 million hectares with 190\% cropping intensity and agricultural crop production is 37.266 million metric tons (DAE-AIS 2013). Agricultural sector provides 29\% of the country's Gross Domestic Production (GDP) and generates employment for $63 \%$ of the total labor force both directly or indirectly. The total area of the country is about 14.8 million hectares (Mha) of which 7.83 Mha are net cultivable area (NCA) (BBS 2011). The situation was different in 1984 - 85 when the NCA was 9.5 Mha (MoEF 2008). The situation appears grim as every year around $0.73 \%$ of valuable agricultural lands are being lost (Imamul Huq and Hassan 2015) to meet up the demands of increased population due to the natural disasters occurring in Bangladesh.

*Author for correspondence: <imamhuq@hotmail.com>. ${ }^{1}$ Center for Environmental and Geographic Information Services (CEGIS), Gulshan, Dhaka-1212, Bangladesh. 
Almost every year Bangladesh suffers highly from different kinds of natural disasters, predominantly drought, salinity, river flood, flash flood, cyclone, storm surge, riverbank erosion, as it is a low lying delta with very gentle slopes (Roy et al. 2009). It has the Himalayan range to the north, the Bay of Bengal to the south with its funneling towards Meghna estuary and the vast stretch of Indian land to the west. The special geographic feature, high spatial and temporal climatic variability, extreme weather events, high population density, high poverty and social inequity, low literacy rate, poor institutional capacity, inadequate financial resources and insufficient infrastructure have made Bangladesh highly vulnerable to natural disasters (Shamsuddin 2010).

The agricultural sector has become more challenging today as sustainable livelihood has become most vulnerable to disasters in Bangladesh. Increase in agricultural production is the only possible way through vertically raising crop yield and improving cropping intensity (CEGIS-FAO 2006). This is one of the major challenges for the agricultural sector, including the issues of national food security. The challenge can be overcome through judicious and scientific utilization of the country's agricultural lands. Farmers should be advised to select suitable, cost-effective cropping patterns and to use updated knowledge for agricultural land management. This would increase agricultural productivity and also benefit the farmers' community (Vakis 2006).

Therefore, the present study was carried out to identify the risks, vulnerabilities and impacts of disasters and to assess the strategies for increasing agricultural production in the disaster affected areas of Bangladesh.

\section{Materials and Methods}

The study areas were selected based on the homogeneity (climate, agricultural practices, agricultural production, disaster risks, livelihood system, population, etc.) of the particular disaster affected areas through random sampling method. It covered 24 Upazillas under 12 districts. Two Upazillas were selected from each of the districts whereas three districts were selected from each category of the disaster (Table 1).

Both qualitative and quantitative data were collected from primary and secondary sources for the assessment of current and future possible risks of disasters and vulnerability of agricultural production in order to ensure sustainable agricultural development.

The study was carried out by identifying relevant information and documentation of the agricultural production, technology, livelihood of the farmers and local people, vulnerable groups of people, vulnerability to different disasters and existing initiatives to combat disasters in disaster vulnerable areas of Bangladesh. Secondary data were collected from scientific reports, publications and proceedings of relevant organizations. Primary data were collected by field investigations through institutional survey, Focus Group Discussion (FGD) and Key Informant Interview (KII) as described in McQueen and Knussen (2002). Standard questionnaire and checklists were prepared for collecting relevant quantitative and qualitative information from the

institutions. Forty eight FGDs were conducted in 24 selected Upazillas following the method as 
described in Boateng (2012). A total of 72 farmers (three farmers from each Upazilla) of different classes viz., marginal, small, medium, large was selected for the FGD and KII. Data and information collection were also done by Upazilla officers and local women. For this purpose, 24 Upazilla officers (one from each upazilla) and 48 women (two from each Upazilla) were selected. After that, a code plan was prepared using an appropriate coding system and a database was developed using Microsoft Excel for the purpose of data entry.

Table 1. Study areas.

\begin{tabular}{lll}
\hline Study areas & District & Upazilla \\
\hline Drought prone & Chapai Nawbganj & Nachole, Gomostapur \\
& Naogaon & Porsha, Sapahar \\
& Natore & Bagatipara, Lalpur \\
\multirow{2}{*}{ River flood prone } & Gaibandha & Gaibandha Sadar, Sundarganj \\
& Kurigram & Chilmari, Raumari \\
& Rangpur & Gangachara, Taraganj \\
Flash flood prone & Sunamganj & Sunamganj Sadar, Jamalganj \\
& Maulvibazar & Kulaura, Baralekha \\
& Habiganj & Baniachang, Ajmeriganj \\
Saline prone & Khulna & Dacope, Terokhada \\
& Noakhali & Subarnachar, Chatkhil \\
& Patuakhali & Kalapara, Mirjaganj \\
\hline
\end{tabular}

Space technology including GIS and remote sensing was extensively used for the analysis and preparation of spatial maps of the study areas. Based on the available baseline data, base maps were prepared using ArcGIS software and GIS data of the national water resource database (NWRD). Besides, after computation of the critical factors in vulnerability, the vulnerability maps were developed considering the impacts and severity of disaster hazards.

\section{Results and Discussions}

The results of the soil properties and net cultivated area (NCA) of the four disaster prone areas are presented in Table 2.

Table 2. Soil properties and net cultivated area of four disaster prone areas.

\begin{tabular}{lcccccc}
\hline Disaster prone area & $\begin{array}{c}\text { Clay } \\
\text { (ha) }\end{array}$ & $\begin{array}{c}\text { Clay loam } \\
\text { (ha) }\end{array}$ & $\begin{array}{c}\text { Loam } \\
\text { (ha) }\end{array}$ & $\begin{array}{c}\text { Sandy loam } \\
\text { (ha) }\end{array}$ & $\begin{array}{c}\text { Sand } \\
\text { (ha) }\end{array}$ & $\begin{array}{c}\text { NCA } \\
\text { (ha) }\end{array}$ \\
\hline Drought & 7 & 18 & 54 & 30 & 11 & 121 \\
Saline & 14 & 33 & 12 & 8 & 1 & 68 \\
River flood & 3 & 8 & 2 & 8 & 9 & 30 \\
Flash flood & 14 & 32 & 49 & 17 & 2 & 115 \\
Total & 38 & 91 & 118 & 64 & 23 & 334 \\
\% & 11 & 27 & 35 & 19 & 7 & 100 \\
\hline
\end{tabular}

Source: Field survey. 
In drought affected areas, the dominant cropping pattern is Fallow - T. Aman - Wheat whereas in saline affected areas, the dominant cropping pattern is Fallow - T. Aman - Pulse. In case of river flood and flash flood areas, dominant cropping pattern is Fallow - T. Aman - HYV Boro (Table 3).

It appeared from the study that the farmers cultivate a number of local, indigenous and HYV varieties in different disaster affected regions according to their choice, yield level, rate of damage reduction, profitability and market demand. It was found that, BR26 is grown in almost all of the disaster affected regions. BRRI dhan48, Mala IRRI, BINA-7, BARI Mustard-7, BARI Potato-20, BARI Wheat-26, etc. are found in large quantities in the drought prone areas. BRRI dhan27, BRRI dhan40, Saitta, Bailam, BARI Lentil-3, BARI Soyabean-5 and Kheshari are found in saline prone areas. The crops grown in the river flood and flash flood affected areas include BR2, BRRI dhan29, Khashiabinni, Biroi, Parijat, Til-6, Tori-7, Shinduri and BARI Mustard-9.

Table 3. Major cropping pattern in four disaster prone areas.

\begin{tabular}{|c|c|c|c|c|}
\hline Hazard prone areas & Kharif-I & Kharif-II & Rabi & Cropping pattern (\%) \\
\hline \multirow[t]{10}{*}{ Drought } & Jute & T. Aman & Pulses & 12 \\
\hline & Fallow & " & Wheat & 20 \\
\hline & " & $"$ & Vegetables & 10 \\
\hline & Jute & $"$ & HYV boro & 10 \\
\hline & Vegetables & " & Potato & 5 \\
\hline & Pulses & $"$ & HYV boro & 15 \\
\hline & Jute & " & Mustard & 3 \\
\hline & Aus & " & HYV boro & 5 \\
\hline & " & " & Spices & 10 \\
\hline & Sugarcane & Sugarcane & Sugarcane & 10 \\
\hline \multirow[t]{6}{*}{ Saline } & Fallow & T. Aman & Fallow & 10 \\
\hline & Aus & " & Soyabean & 10 \\
\hline & Fallow & $"$ & Watermelon & 25 \\
\hline & " & " & Pulses & 35 \\
\hline & " & " & Fallow & 25 \\
\hline & Aus & Fallow & Water melon & 5 \\
\hline \multirow[t]{4}{*}{ River flood } & Jute & T. Aman & Boro & 25 \\
\hline & Fallow & " & Mustard/HYV & 30 \\
\hline & $"$ & $"$ & HYV boro & 35 \\
\hline & Vegetables & Fallow & Vegetables & 10 \\
\hline \multirow[t]{8}{*}{ Flash flood } & Fallow & T. Aman & Fallow & 20 \\
\hline & " & " & Boro & 30 \\
\hline & " & Fallow & " & 30 \\
\hline & " & " & Vegetables & 2 \\
\hline & Vegetables & T. Aman & Boro & 5 \\
\hline & Fallow & Aman & Mustered & 5 \\
\hline & " & " & Vegetables & 6 \\
\hline & $"$ & Fallow & Groundnut & 2 \\
\hline
\end{tabular}

Source: Field survey. 
Thirty year (1984-2013) trend in four types of disaster prone areas is presented in Table 4.

Table 4. Thirty years trend in cropped area in four disaster prone areas.

\begin{tabular}{|c|c|c|c|c|c|c|c|c|c|}
\hline \multirow[t]{2}{*}{ Crop } & \multicolumn{4}{|c|}{ Cropped area (ha) in drought areas } & \multicolumn{5}{|c|}{ Cropped area (ha) in saline areas } \\
\hline & 1984 & 1994 & 2004 & 2013 & Crop & 1984 & 1994 & 2004 & 2013 \\
\hline Aus & 4.6 & 4.18 & 3.8 & 3.45 & HYV Boro & 1 & 1 & 1 & 1 \\
\hline T. Aman & 20.59 & 18.72 & 17.01 & 15.47 & HYV Aman & 18 & 15 & 14 & 13 \\
\hline Boro & 36.93 & 40.58 & 45.61 & 60.01 & HYV Aus & 4 & 4 & 3 & 3 \\
\hline Jute & 36.56 & 5.77 & 15.02 & 14.31 & Spices & 0.2 & 0.1 & 0.1 & 0.1 \\
\hline Wheat & 2.86 & 2.72 & 2.59 & 2.47 & Watermelon & 0.5 & 0.4 & 0.4 & 0.4 \\
\hline Potato & 1.14 & 1.09 & 1.04 & 0.99 & Soybean & 0 & 0 & 0 & 1 \\
\hline Mustard & 17.13 & 16.32 & 15.54 & 14.8 & Groundnut & 0.6 & 0.6 & 0.6 & 1 \\
\hline Pulse & 1.14 & 1.09 & 1.04 & 0.99 & Pulse & 0.3 & 0.3 & 0.3 & 0.3 \\
\hline Vegetables & 3.43 & 3.26 & 3.11 & 2.96 & Vegetables & 0.8 & 0.7 & 0.7 & 1 \\
\hline \multirow[t]{2}{*}{ Crop } & \multicolumn{4}{|c|}{ Cropped area (ha) in river flood areas } & Crop & \multicolumn{4}{|c|}{ Cropped area (ha) in flash flood areas } \\
\hline & 1984 & 1994 & 2004 & 2013 & & 1984 & 1994 & 2004 & 2013 \\
\hline HYV Boro & 17.13 & 16.32 & 15.54 & 14.8 & Aman & 49.25 & 44.77 & 40.7 & 37 \\
\hline Local Boro & 2.86 & 2.72 & 2.59 & 2.47 & & & & & \\
\hline HYV Aus & 0.66 & 0.6 & 0.54 & 0.49 & Boro & 52.69 & 51.65 & 51.65 & 50.64 \\
\hline LocalAus & 1.64 & 1.49 & 1.36 & 1.23 & & & & & \\
\hline Jute & 8.28 & 7.89 & 7.51 & 7.15 & Mustard & 4.62 & 4.53 & 4.53 & 4.44 \\
\hline Wheat & 1.43 & 1.36 & 1.3 & 1.23 & & & & & \\
\hline Onion & 1.43 & 1.36 & 1.3 & 1.23 & Groundnut & 1.05 & 1.03 & 1.03 & 1.01 \\
\hline Chili & 2.38 & 2.27 & 2.16 & 2.06 & & & & & \\
\hline Pulse & 0.57 & 0.54 & 0.52 & 0.49 & Potato & 0.76 & 0.74 & 0.74 & 0.73 \\
\hline Vegetables & 1.71 & 1.63 & 1.55 & 1.48 & Vegetables & 7 & 7 & 6 & 6 \\
\hline
\end{tabular}

Source: Field survey.

The trend analysis for 30 years (1984 - 2013) of cropped area in four disaster prone areas shows that the overall cropped area decreased by 1\% from 1984 to 2013. It was observed that, in case of drought prone areas, the cropped area of Aus and Aman is decreased by $25 \%$, jute by $61 \%$, wheat, mustard and pulse by $14 \%$. However, the cropped area of Boro crop has increased by $62 \%$. In saline regions, the area under HYV Boro remained static throughout the period because of salinity problems in dry season. In the river flood prone areas, the maximum cropped area was decreased by $25 \%$ in case of Aus and the minimum by $13 \%$ in the case of vegetables. It was revealed that the Aman cropped area was decreased by about $25 \%$.

The maximum cropping intensity was found in drought prone areas, which is followed by flash flood prone, saline prone and river flood prone areas (Fig. 1).

The highest production of HYV Boro, local and HYV Aman was found in flash flood prone areas (Table 5), although these crops are mainly vulnerable to flash floods because of the timing of the disaster. On the contrary, Aus is mainly produced in drought prone areas along with Hybrid Boro, jute and sugarcane. 


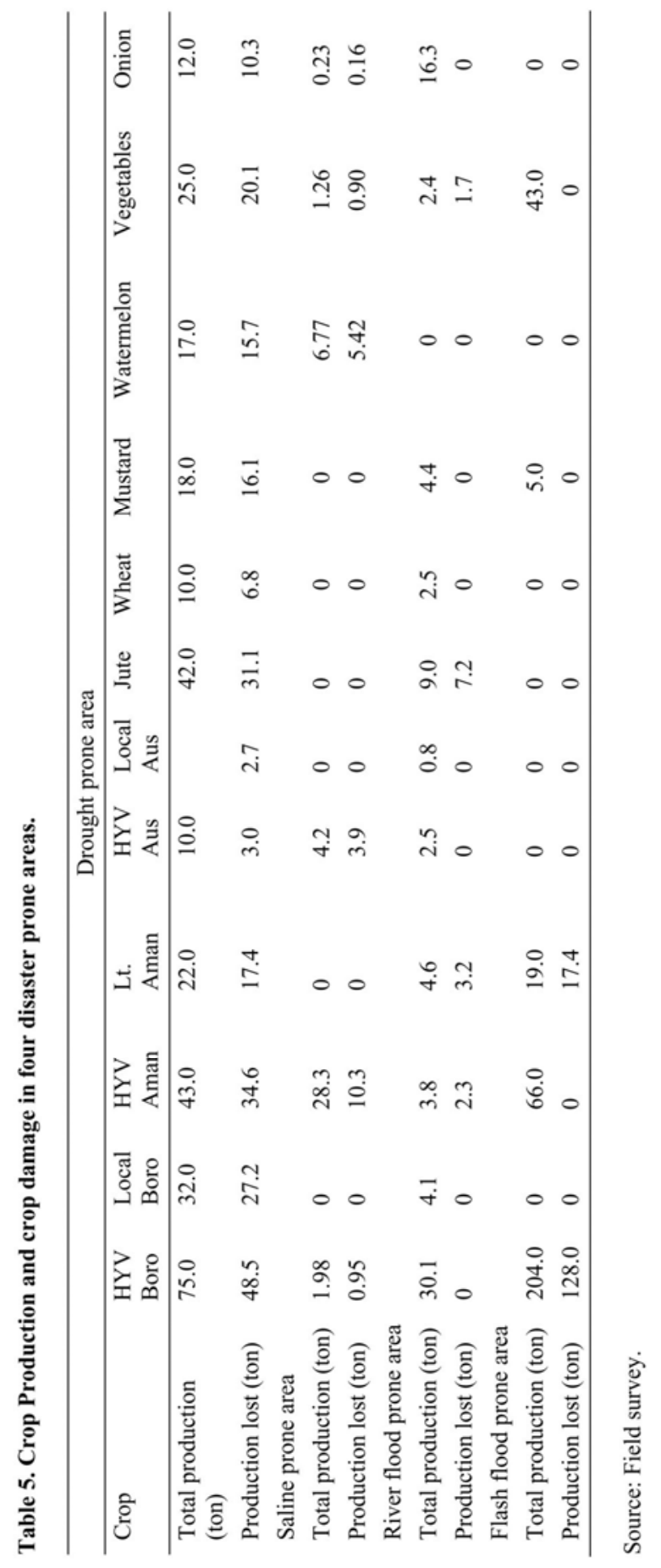


It was revealed that, in drought affected areas, the maximum production loss is due to the Boro (Hybrid), Aman (HYV), jute, potato, mustard, onion, chili and vegetables (both summer and winter vegetables). In flash flood areas, both the HYV Boro and Local Aman crops face the highest production loss. However, there is no significant production loss in the saline and river flood affected areas.

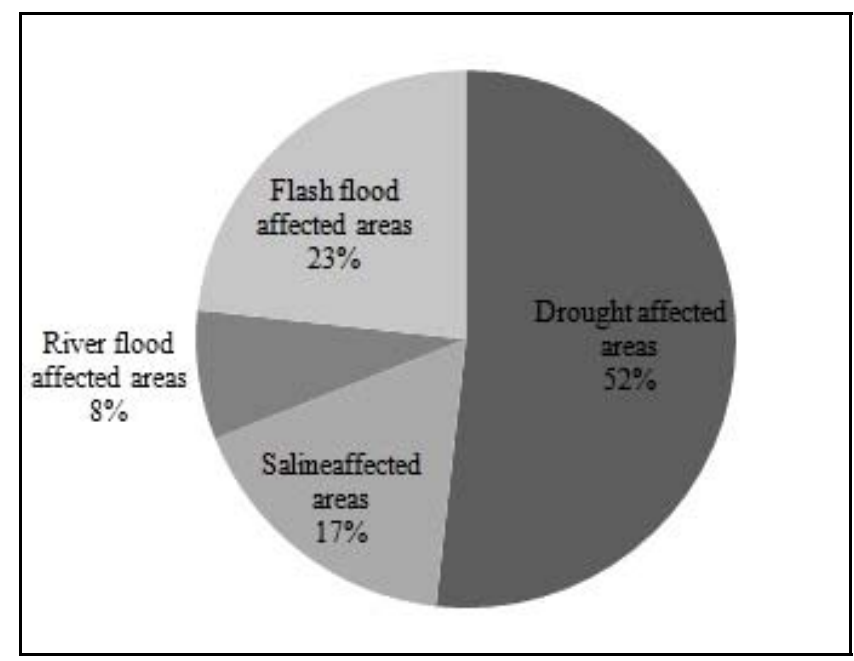

Fig. 1. Cropping intensity in four disaster affected areas of Bangladesh.

It is apparent from the present study that, the vulnerability in the agricultural sector varies according to the regional and temporal variation of natural disasters in the vulnerable areas of Bangladesh. It was observed that, among 72 farmers, about 85, 90, 69 and 95\% are vulnerable to the risk of drought, salinity, river flood and flash flood, respectively.

Fig. 2 indicates that, in case of drought, salinity as well as river flood, the percentage of response was below 50 indicating that risk to other causes was not severe for those farmers. However, in flash flood prone region, the response was more than $50 \%$ against the risk of hail storm and flood and 50\% against the risk of drought which indicates that the farmers were also vulnerable to flood, hail storm and drought.

It was found that, the farmers become highly vulnerable to drought from February to May and September to October in drought prone regions. Similarly, February to May is the most vulnerable time for farmers in terms of crop cultivation in the saline regions. Monsoon (April to September) is the peak vulnerable month for both the river flood and flash flood affected areas, although early rise of river may damage standing Boro crops during April to May. 

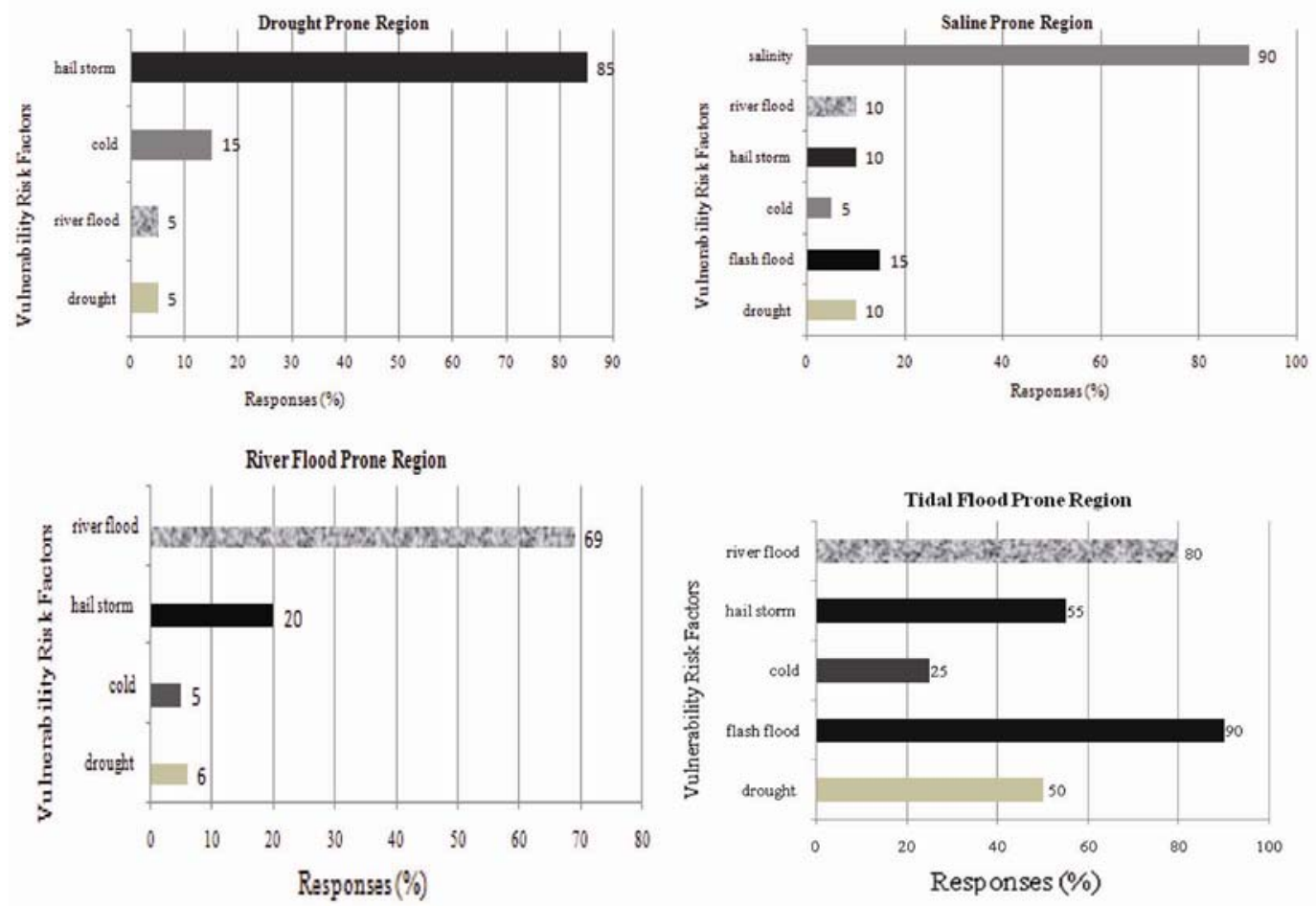

Fig. 2. Regional variation of disaster vulnerability factors.

The present study revealed that most of the farmers in disaster affected areas follow the double cropping pattern. Triple cropping pattern is found particularly in saline prone regions due to the availability of agricultural inputs and irrigation facilities. From the study it was found that cultivable land remains fallow more during Kharif-I in the drought (65\%), saline (96\%) and flash flood (65\%) affected areas. However, in river flood affected regions, fallow land is found to be more during Kharif-II (64\%). Fig. 3 shows that medium high land is the most vulnerable to disasters. Due to vulnerability to disasters, medium high land remains fallow in saline (83\%), river flood (51\%) and flash flood (31\%) areas. On the other hand, medium low land (37\%) remains fallow in drought prone regions.

According to the response, it is evident that high land $\left(\mathrm{F}_{0}=0-30 \mathrm{~cm}\right)$ is the most vulnerable for all kinds of farmers (marginal, small, medium and large) with respect to agricultural production in almost all disaster prone areas. Medium low land $\left(F_{2}=90-180 \mathrm{~cm}\right)$ is suitable for production, but this type of land is not common in the drought and saline prone regions. In river and flash flood affected areas, a significant number of farmers have low land $\left(\mathrm{F}_{3}=180-300 \mathrm{~cm}\right)$ and very low land $\left(\mathrm{F}_{4}=>300 \mathrm{~cm}\right)$. It was found that farmers having low land and very low land are more vulnerable to the two types of floods. 

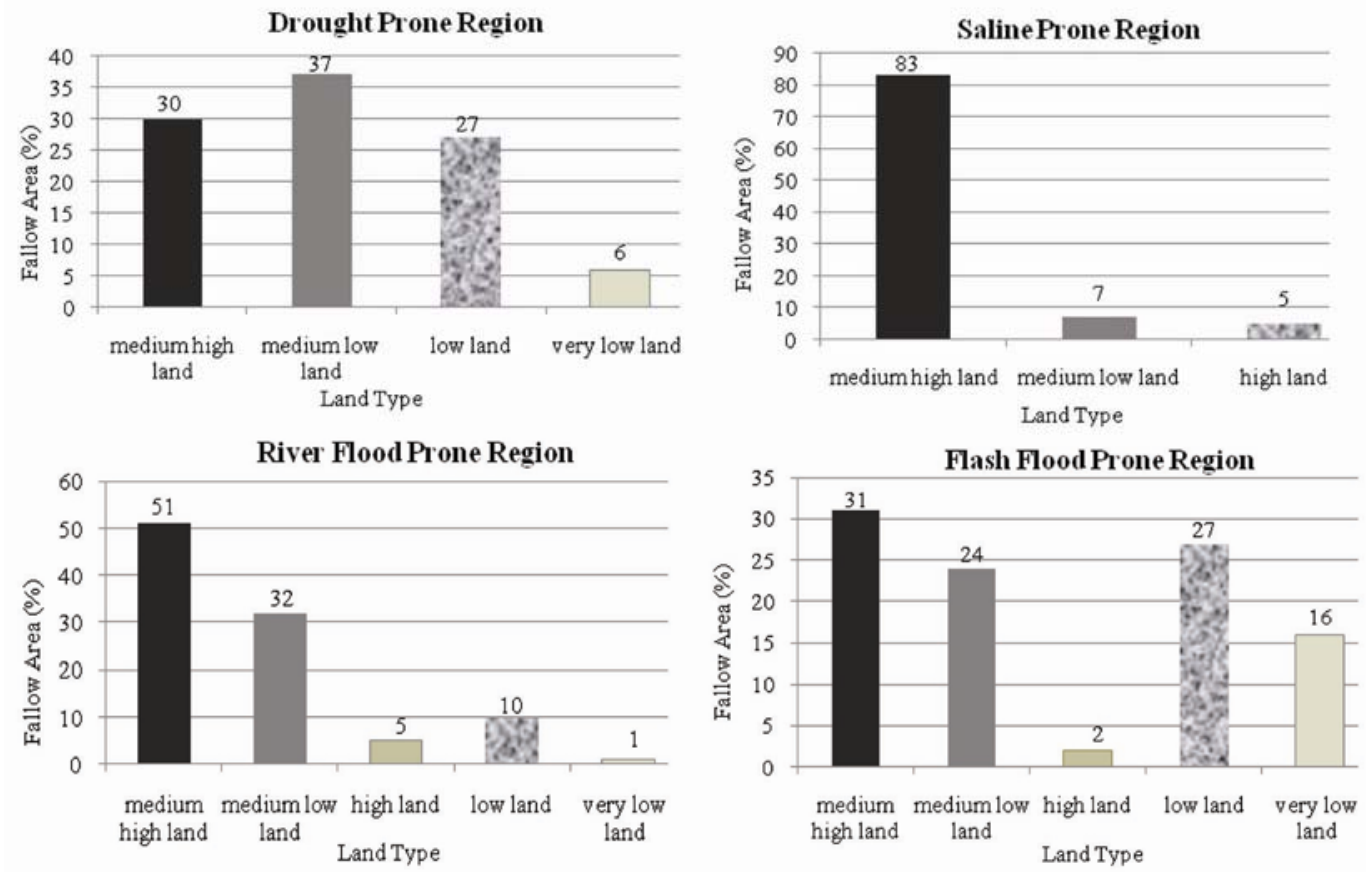

Fig. 3. Area percentage of fallow land in four disaster prone areas by land type.

It appeared from the present study that $\mathrm{T}$. Aman is one of the most common crops practiced by all types of farmers during Kharif-II season by keeping the land fallow in Kharif-I. During Rabi and Kharif-I, crops are more vulnerable to drought and most crops are lost due to the lack of irrigation water and delayed rainfall. Drought in March-April prevents land preparation and ploughing activities while drought in May-June destroys B. Aman, Aus and jute. Inadequate rainfall in August delays transplantation of Aman in high land while drought in SeptemberOctober reduces the yield of both broadcast and transplant Aman. In saline prone regions, the fallow-T. Aman-fallow pattern is observed more frequently which makes all types of farmers highly vulnerable to salinity, especially during Rabi season. As saline intrusion becomes high during Rabi season, rice cannot be cultivated, especially by marginal and small farmers. However, no highly vulnerable cropping pattern was found in river flood affected areas. In flash flood prone regions, fallow-fallow-Boro is found to be more vulnerable particularly for marginal and small farmers as the flood damages standing Boro crop during peak harvesting period.

It was found that average rice cropped area is decreased by about $1 \%$ annually in all disaster affected regions mostly due to climatic variation and urbanization. If it continues, the total cropped area of rice, non-rice and vegetables would be decreased 30\% by 2042 (30 years after) from the present cropped area (Fig. 4). 

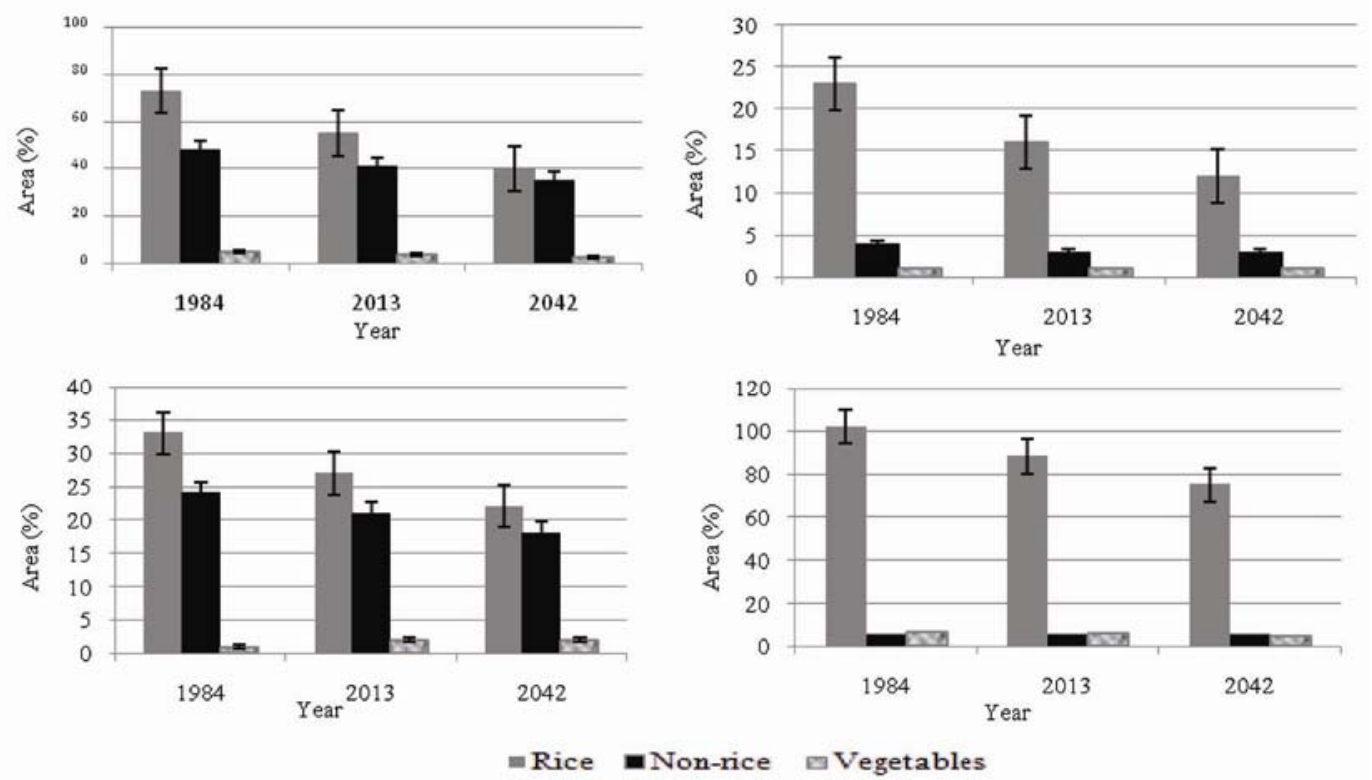

Fig. 4. Cropped area of rice, non-rice and vegetables in 1984 (30 years ago) to 2042 (30 years after).

\section{Conclusion}

Agriculture represents a key sector for providing economic and social development in Bangladesh, and it is anticipated that disaster risks can have negative impacts on agriculture. The extent of these impacts largely depends on the ability of people for facing vulnerabilities of disasters which requires immediate efforts to build resilience and adaptive capacity. Key strategies for adaptation to disasters in the agricultural sector must be based on the principles of sustainable development and diversification. Productivity rate is to be improved to meet the dual challenge of achieving food security and generating sufficient food to meet the increasing demand. Farmers of our country utilises both indigenous farming knowledge and selected modern technologies to minimize the harmful impacts of disasters. It is adaptable to both small and large scale farming systems which ultimately leads to enhanced productivity.

\section{Reference}

Bangladesh Bureau of Statistics (BBS). 2011. Statistical Yearbook of Bangladesh. Statistics Division, Ministry of Planning, Government of the People’s Republic of Bangladesh, Dhaka.

Boateng, W. 2012. Evaluating the Efficacy of Focus Group Discussion (FGD) in Qualitative Social Research. Int. J. Business \& Social Sci. 3(7): 156-175.

CEGIS-FAO. 2006. Study on Livelihood Systems Assessment, Vulnerable Groups Profiling and Livelihood Adaptation to Climate Hazard and Long-term Climate Change in Drought Prone Areas of North-West Bangladesh. Centre for Environmental Geographic Information Services (CEGIS) and Food and Agricultural Organization of the United Nations (FAO), Dhaka, Bangladesh. 
Department of Agriculture Extension-Agriculture Information Services (DAE-AIS). 2013. Agricultural Statistics, Policy and Planning Support Unit, Ministry of Agriculture, Government of the People's Republic of Bangladesh.

Imamul Huq, S. M. and M. N. Hassan. 2015. Sustainable Management and Protection of Soil Resources. Bangladesh country Paper presented at the Workshop on Sustainable management and Protection of Soil Resources, held at Bangkok, Thailand during 13-15 May, 2015, organized by Global Soil Partnership of FAO.

McQueen, R. A. and C. Knussen. 2002. Research Methods for Social Science: A Practical Introduction. Prentice Hall, US.

Ministry of Environment and Forest (MoEF). 2008. Characterizing Long-term Changes of Bangladesh Climate in Context of Agriculture and Irrigation. Climate Change Cell, Ministry of Environment and Forest, Dhaka.

Roy, K. K., U. Mehedi, H. Sultana and D. M. Ershad. 2009. Initial Damage Assessment Report of Cyclone AILA with Focus on Khulna district. Unnayan Onneshan, Humanity Watch, Nijera Kori, Bangladesh.

Shamsuddin, S. 2010. Probable Impacts of Climate Change on Public Health in Bangladesh. Asia Pac. J. Public Health 22(3): 310-319.

Vakis, R. 2006. Complementing Natural Disasters Management: The Role of Social Protection. The World Bank. pp. 2. 